\title{
COMPARISON OF HEMATOXYLIN \& EOSIN (H\&E) STAINING AND PERIODIC ACID SCHIFF-ALCIAN BLUE (PAS-AB) HISTOCHEMISTRY IN ESOPHAGEAL BIOPSIES IN TERMS OF INTESTINAL METAPLASIA
}

\section{ÖZOFAGUS BIYYOPSILERINDE HEMATOXYLIN \& EOSIN (H\&E) BOYAMASININ VE PERIYYOIIK ASITT SCHIFF-ALCIAN BLUE (PAS-AB) HISTOKIMMYASININ INTESTINAL METAPLAZİ AÇISINDAN KARŞILAŞTIRILMASI}

\author{
Ozge ERTENER', Gulname FINDIK GUVENDI'², Yasemen ADALI ${ }^{3}$
}

\begin{abstract}
Özet
Barret özofagusu, özofagus adenokarsinomları için öncül bir lezyon olarak kabul edilir. Endoskopik incelemenin önemli yer tuttuğu Barret özofagusu için histopatolojik inceleme gereklidir. Histopatolojik incelemelerde hematoksilen \& eozin (H\&E) ve alcian blue (AB) ile intestinal metaplazi ortaya çıkarılır. Bu konuda 2 farklı görüş mevcuttur. Bunlardan biri, rutin H\&E boyamasında intestinal metaplaziden şüphelenildiğinde $\mathrm{AB}$ veya Periodic acid schiff alcian blue (PAS-AB) için histokimyasal inceleme yapmak, diğeri ise tüm özofagus biyopsilerinde $\mathrm{H} \& \mathrm{E}$ boyaması yanı sıra rutin olarak $\mathrm{AB}$ veya $\mathrm{PAS}-\mathrm{AB}$ ile histokimyasal inceleme yapmaktır. $\mathrm{Bu}$ çalışma, intestinal metaplazinin değerlendirilmesinde $H \& E$ ve $A B$ boyama yöntemlerinin rolünü ortaya koymayı amaçlamaktadır. Çalışmaya 200 özofagus endoskopik biyopsisi dahil edildi. Biyopsi kesitleri iki patolog tarafindan kör olarak yeniden değerlendirildi. H\&E ve Periodic acid schiff alcian blue (PAS-AB) boyaları sensitivite, spesifite ve pozitif prediktivite açısından karşılaştırıldı. İstatistiksel analizde intestinal metaplazinin değerlendirilmesinde $\mathrm{H} \& \mathrm{E}$ ve $\mathrm{AB}$ arasında güçlü bir korelasyon bulundu (Kendall, $\mathrm{p}=$ 0,$00 ; \mathrm{r}=0,81$ ). PAS-AB boyalı kesitlerde sensitivite $\% 100$, spesifite $\% 100$, pozitif prediktivite $\% 100$, negatif prediktivite $\% 100$ iken; H\&E değerlendirmesinde, sensitivite $\% 79$, spesifite $\% 100$, pozitif prediktivite $\% 100$, negative prediktivite $\% 82.6$ 'dır. İntestinal metaplazinin histopatolojik değerlendirmesinde temel amaç pozitif olguları tespit etmektir. İntestinal metaplazinin yokluğu daha az önemli olduğundan H\&E kesitlerde gözlenen \% 100 spesifite ve pozitif prediktivite değerleri yerine; daha yüksek sensitivite ve negatif prediktivite değerleri tercih edilmelidir. Bu koşullar göz önünde bulunduruldğunda, $\mathrm{AB}$ içeren yardımcı bir histokimya kullanmak mantıklı görünmektedir.
\end{abstract}

Anahtar Kelimeler: İntestinal metaplazi, Hematoksilen\& Eozin, H\&E, Alcian blue, AB

\section{Abstract}

In this study, it was aimed to evaluate the effects of ultrasound application applied to yoghurt samples produced in laboratory environment at different stages of production (before and after fermentation) on the water holding capacity, homogenization, and shelf life of yoghurts. In order to achieve this aim, microbiological and physicochemical analyzes were performed on the $1^{\text {st }}, 7^{\text {th }}$ and $15^{\text {th }}$ days of the yoghurt groups at $2-4{ }^{\circ} \mathrm{C}$ cold storage. It was determined that there was an increase of $0.5 \log$ in the number of $L$. delbrueckii subsp. bulgaricus in each group on the $7^{\text {th }}$ day. According to the results of the $7^{\text {th }}$ day in the ultrasound after inoculation $(\mathrm{I}+\mathrm{U})$ group, it was found that there was a 1 log decrease in the number of $S$. thermophilus. The highest yeast count was determined at $5.02 \mathrm{log} \mathrm{cfu} / \mathrm{g}$ in $15^{\text {th }}$ day samples of again $\mathrm{I}+\mathrm{U}$ group. The water holding capacity in the control, inoculation after ultrasound $\mathrm{U}$ $+\mathrm{I}$ and I + U groups was determined respectively $28.45 \%, 52.96 \%, 46.48 \%$ in the first day analyzes, $34.49 \%, 48.17 \%, 50,52 \%$ in the $7^{\text {th }}$ day analyzes, and $31.34 \%, 54.84 \%$ and $47.84 \%$ in the $15^{\text {th }}$ day analysis. Also, in homogenization efficiency a significant difference between the control group, $\mathrm{U}+\mathrm{I}$ and $\mathrm{I}+\mathrm{U}$ groups has been determined. The highest homogenization efficiency was detected in I+ $\mathrm{U}$ group at $3.03 \%$ level. In the control, $\mathrm{U}+\mathrm{I}$ and $\mathrm{I}+\mathrm{U}$ groups $\mathrm{L}$ value averages, in color analysis on the $15^{\text {th }}$ day were determined as $81.55 ; 85.56$; and 84.46 respectively. As a result, it was determined that in ultrasound applications yoghurt bacterial counts, $\mathrm{pH}$ and titration acidity values did not cause a defect that would affect taste and aroma during storage under cold storage conditions. In addition, in terms of water holding capacity, homogenization efficiency and L value during storage, it has been determined that ultrasound applications improve the rheological properties of yoghurt and increase its durability under cold storage conditions. Keywords: Ultrasound, yoghurt, shelf life, water holding capacity, homogenization.

Geliş Tarihi (Received Date):16.06.2021, Kabul Tarihi (Accepted Date):19.08.2021, Basım Tarihi (Published Date): 30.09.2021 ${ }^{1-3}$ İzmir Ekonomi Üniversitesi, Tıp Fakültesi, İzmir, Türkiye, ${ }^{2}$ Recep Tayyip Erdoğan Üniversitesi, Tıp Fakültesi, Rize, Türkiye E-mail: ozge.ertener@gmail.com, ORCID ID's: Ö.E; https:/orcid.org/0000-0002-49577877, G.F.G.; https:/orcid.org/0000-0001-9370-4880, Y.A.; https:/orcid.org/0000-0002-8004-7364 
Ertener et al.

\section{INTRODUCTION}

Gastroesophageal reflux disease (GERD) is an important health problem due to its increasing frequency and affecting the quality of life (Bujanda and Hachem, 2018, pp. 211213). It was reported in the survey studies that GERD symptoms were described at least once a week in approximately $20 \%$ of the adult population in United States of America (USA) (Locke et al, 1997, pp. 1448-1456).

Barret's esophagus can be considered as a sign of GERD in addition to the heart burn, regurgitation of stomach contents, and esophageal inflammation. Barret's esophagus is caused by the continuous irritation of esophagus and is closely related with esophageal adenocarcinomas (Pech, 2019, pp.210-214). Barret's esophagus is usually defined as segment of intestinal metaplasia in the distal esophagus of more than $10 \mathrm{~mm}$ in length (Weusten et al, 2017, pp.191-198). Although GERD is common in the adult population in the USA, it is reported that Barret's esophagus develops in only 10-15\% of the cases (Katz et al, 2013, pp. 308-28; Shaheen et al., 2016, pp.30-50). In addition, cases with Barret's esophagus and / or adenocarcinoma without GERD symptoms have been reported (Hayeck et al, 2010, pp. 451457; Gerson et al. 2002, pp. 461-467).

The estimated incidence of Barret's esophagus in the USA is reported to be $5.6 \%$. Changes in living conditions, obesity, tobacco use, frequent consumption of foods containing caffeine, foods that increase the risk of reflux, stress, etc. increase the frequency of reflux, while the incidence of intestinal metaplasia is gradually increasing (Weusten et al, 2017, pp. 191-198; Shaheen et al, 2016, pp.30-50 ; Peters et al, 2019, pp.35 ). For this reason, detection of intestinal metaplasia in esophageal sampling is very important in terms of the chance to intervene in the carcinogenetic process at an early stage.

The diagnosis of Barret's esophagus is made endoscopically and histologically (Shalauta and Saad, 2004, pp. 2113-2118). The presence of intestinal metaplasia is evaluated histopathologically in endoscopic biopsies taken from the Barret's esophagus areas, which are observed as areas different from the surrounding mucosa and salmon color above the $\mathrm{Z}$ line in endoscopic imaging (De palma, 2012, pp. 6216-6225). Moreover, the presence of inflammation, its severity and activity, the presence and severity of dysplasia are also evaluated in esophageal biopsies in addition to intestinal metaplasia (Fiocca et al, 2011, pp. 319-330).

In esophageal biopsies, histopathological evaluation is performed on hematoxylin \& eosin (H\&E) sections after routine tissue processing. Alcian blue (AB) or periodic acid schiffalcian blue (PAS-AB), which clearly show intestinal metaplasia, are evaluated together with routine $H \& E$ sections in many centers. There are 2 different opinions on this issue. One of them is to perform histochemical examination for $\mathrm{AB}$ or PAS-AB when intestinal metaplasia is suspected in routine $H \& E$ staining, while the other is to perform histochemical examination for routine $\mathrm{AB}$ or $\mathrm{PAS}-\mathrm{AB}$ in all esophageal biopsies with $\mathrm{H} \& \mathrm{E}$ section. There is no study showing the advantages or disadvantages of these two accepted views. In this study, it is aimed to compare the two methods mentioned. 


\section{MATERIAL AND METHODS}

The retrospectively planned study was designed in accordance with the World Medical Association Declaration of Helsinki and does not include any application on humans. Ethics committee approval was obtained from the Ethics Committee of Health Sciences University Tepecik Training and Research Hospital, Izmir with the decision dated 22/02/2021 and numbered 2021/ 02-72. In this technique study, which was planned as a review of the archive material, 200 previously reported biopsies that belong to adults with known intestinal metaplasia situation were included. The sections of the cases were obtained from the pathology preparation archive and re-evaluated blindly by two pathologists. In the evaluation, H\&E sections were examined first and the results of intestinal metaplasia were noted. Later, PAS$\mathrm{AB}$ sections were examined and intestinal metaplasia results were determined.

SPSS 15. 0 package program (SPSS Inc. Released 2006. SPSS for Windows, Version 15.0. Chicago, SPSS Inc.) was used for statistical analysis. In the study, sensitivity, specificity, positive and negative predictivity values were calculated according to the formulas given below based on table-1.

Table-1: The calculation of sensitivity, specificity, positive and negative predictive values *Formulas: Sensitivity: a / $(\mathrm{a}+\mathrm{c})$ x 100; Specificity: d / (b+d) x 100; Positive Predictive Value: a / $(a+b)$ x 100; Negative Predictive Value: d / (c+d) x 100

\begin{tabular}{|c|c|c|c|}
\hline \multirow{2}{*}{$\begin{array}{c}\text { Methods } \\
\text { H\&E, PAS-AB) }\end{array}$} & \multicolumn{2}{|c|}{ Gold standard Method (Biopsy report) } \\
\cline { 2 - 4 } & Positive & Negative & Total \\
\hline Positive & a (True positive) & $\mathrm{b}$ (False positive) & $\mathrm{a}+\mathrm{b}$ \\
\hline Negative & $\mathrm{c}$ (True negative) & $\mathrm{d}$ (False negative) & $\mathrm{c}+\mathrm{d}$ \\
\hline Total & $\mathrm{a}+\mathrm{c}$ & $\mathrm{b}+\mathrm{d}$ & \\
\hline
\end{tabular}

\section{RESULTS}

Intestinal metaplasia was detected in $79(39.5 \%)$ cases in routine examination with H\&E staining, while intestinal metaplasia was detected in 100 (50\%) cases with PAS-AB staining. The evaluation of $\mathrm{H} \& \mathrm{E}$ and $\mathrm{PAS}-\mathrm{AB}$ stained cases according to the presence of intestinal metaplasia is presented in table-2. Besides the evaluation, the intestinal metaplasia results are scored. With H\&E staining 121 cases $(60.5 \%)$ were scored " 0 ", 59 cases $(29.5 \%)$ were scored " 1 ", 10 cases $(10 \%)$ were scored " 2 " and 10 cases (10\%) were scored " 3 ". On the other hand, 100 cases $(50 \%)$ were scored " 0 ", 80 cases $(40 \%)$ were scored "1", 10 cases $(10 \%)$ were scored " 2 " and 10 cases $(10 \%)$ were scored " 3 " by PAS-AB staining. The examination according to intestinal metaplasia scores is presented in table-3. Examples of intestinal meaplasia positive cases evaluated by $\mathrm{H} \& \mathrm{E}$ and $\mathrm{PAS}-\mathrm{AB}$ staining are demonstrated by figures $1-3$. In statistical 


\section{Comparison of hematoxylin \& eosin $(H \& E)$ staining and periodic acid schiff-alcian blue}

\section{(PAS-AB) histochemistry in esophageal biopsies in terms of intestinal metaplasia}

Ertener et al.

analysis, a strong correlation was found between $H \& E$ and $A B$ in the evaluation of intestinal metaplasia (Kendall, $\mathrm{p}=0.00 ; \mathrm{r}=0.81$ ). In $\mathrm{H} \& \mathrm{E}$ evaluation, sensitivity is $79 \%$, specificity $100 \%$, positive predictivity $100 \%$, negative predictivity $82.6 \%$, while sensitivity is $100 \%$, specificity $100 \%$, positive predictivity $100 \%$, negative predictivity $100 \%$ in PAS-AB stained sections. These values are are presented in table- 4 .

Table-2: Evaluation of $\mathrm{H} \& \mathrm{E}$ and PAS-AB stained cases according to the presence of intestinal metaplasia

\begin{tabular}{|l|l|l|}
\hline Intestinal metaplasia & H\&E & PAS-AB \\
\hline Present & $79(39.5 \%)$ & $100(50 \%)$ \\
\hline Absent & $121(60.5 \%)$ & $100(50 \%)$ \\
\hline
\end{tabular}

Table-3: Evaluation of $\mathrm{H} \& \mathrm{E}$ and PAS-AB stained cases according to intestinal metaplasia scores

\begin{tabular}{|l|l|l|}
\hline Score & H\&E & PAS-AB \\
\hline 0 & $121(60.5 \%)$ & $100(50 \%)$ \\
\hline 1 & $59(29.5 \%)$ & $80(40 \%)$ \\
\hline 2 & $10(10 \%)$ & $10(10 \%)$ \\
\hline 3 & $10(10 \%)$ & $10(10 \%)$ \\
\hline
\end{tabular}

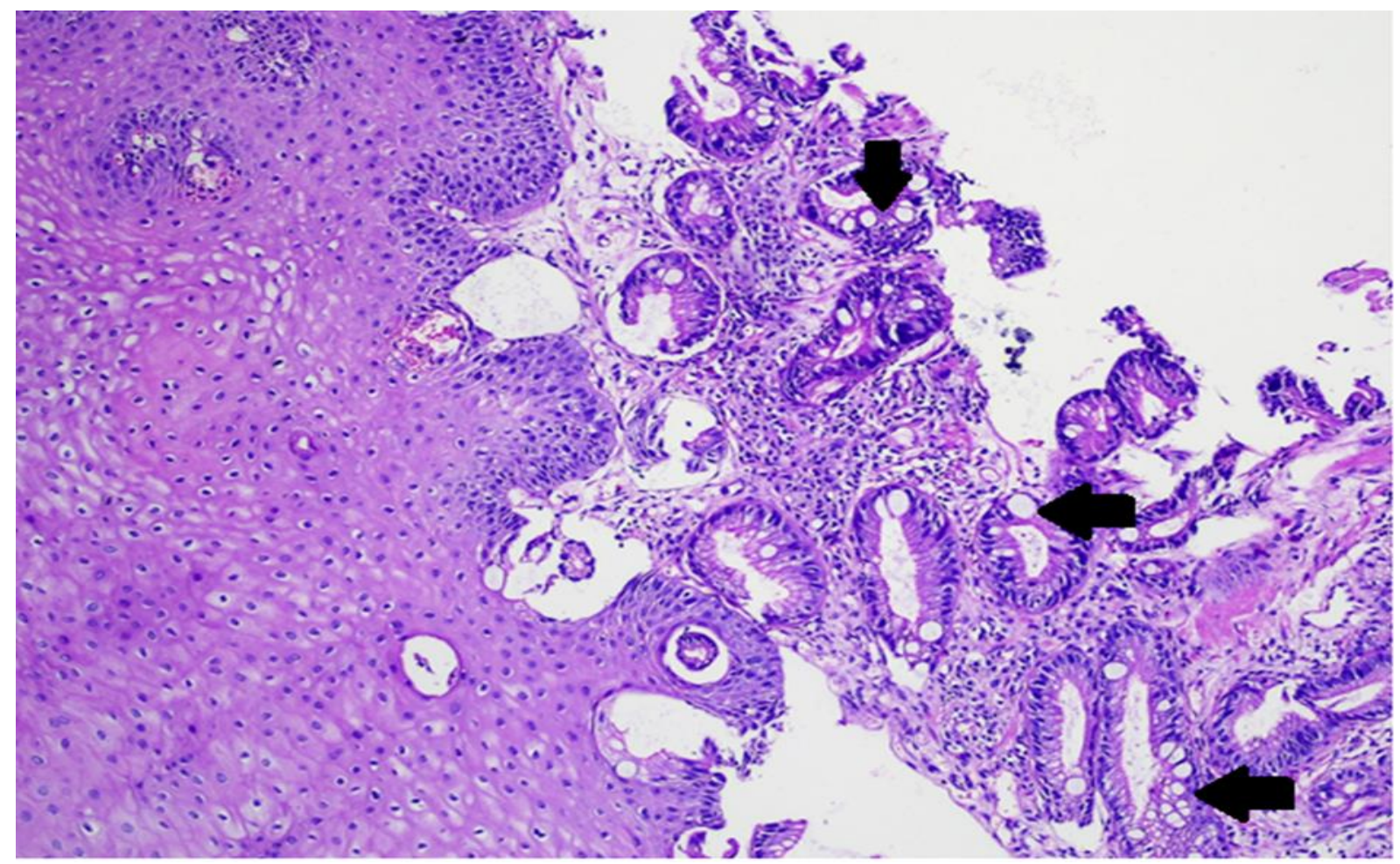

Figure-1: Intestinal metaplasia (black arrows) in esophageal biopsy, H\&E staining, $\times 400$ magnification. 
Comparison of hematoxylin \& eosin $(H \& E)$ staining and periodic acid schiff-alcian blue

(PAS-AB) histochemistry in esophageal biopsies in terms of intestinal metaplasia

Ertener et al.

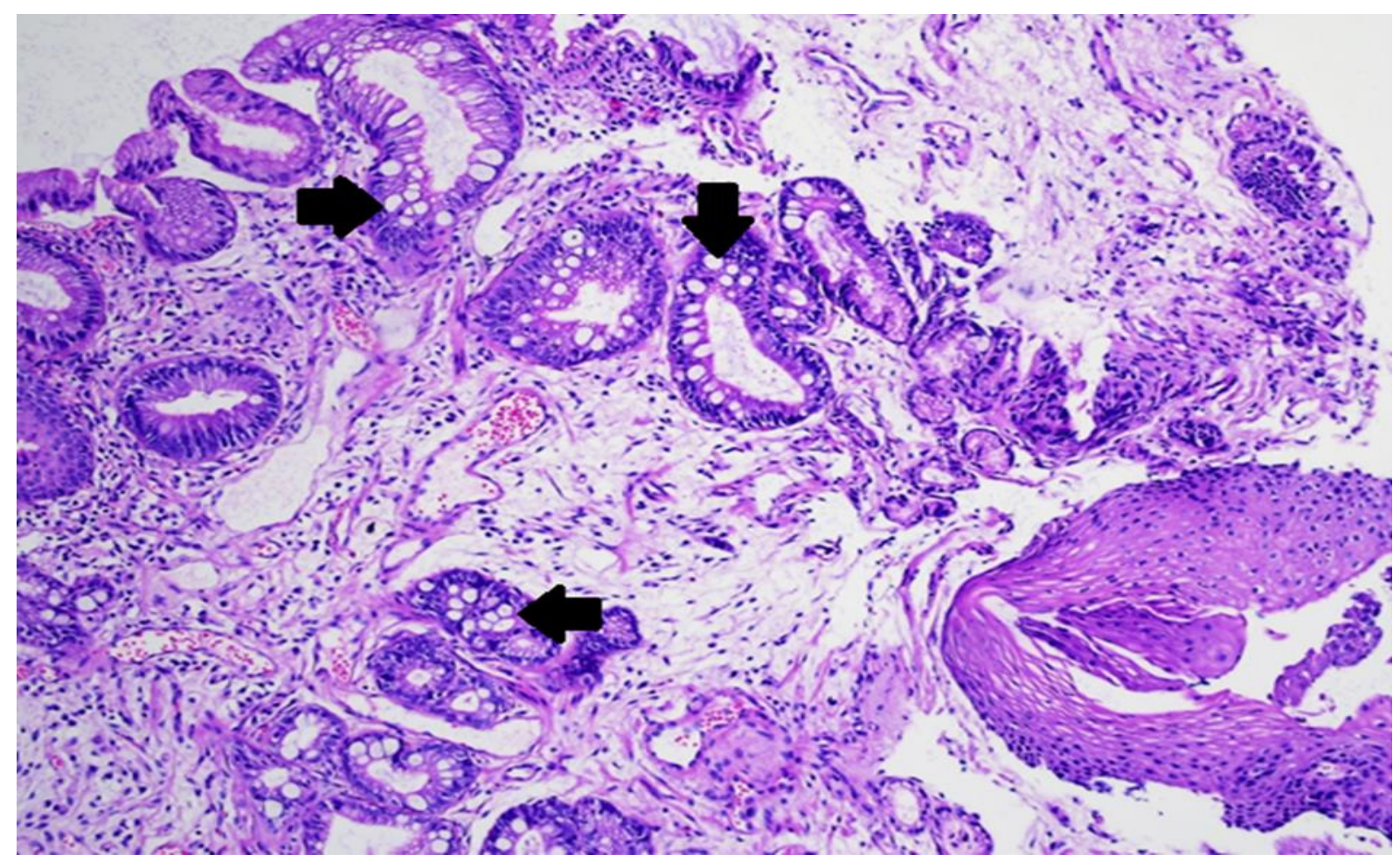

Figure-2: Intestinal metaplasia (black arrows) in esophageal biopsy, H\&E staining, $\times 400$ magnification.

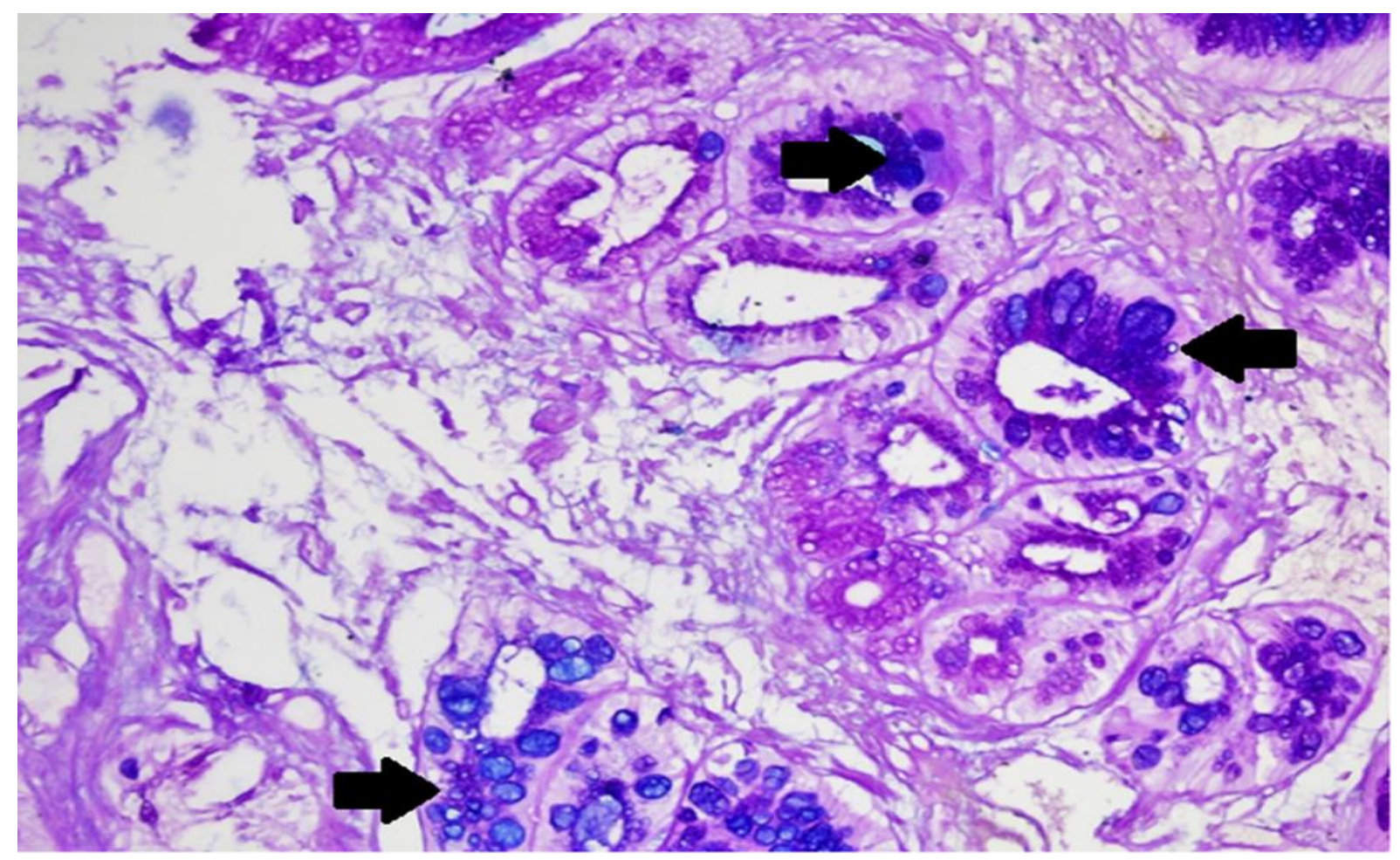

Figure-3: Intestinal metaplasia (black arrows) in esophageal biopsy, PAS-Alcian Blue staining, $\times 400$ magnification. 
Table-4: Sensitivity, specificity, positive predictive value and negative predictive values for $\mathrm{H} \& \mathrm{E}$ and PAS-AB

\begin{tabular}{|l|l|l|c|c|}
\hline & Sensitivity & Specificity & $\begin{array}{l}\text { Positive predictive } \\
\text { value }\end{array}$ & $\begin{array}{l}\text { Negative predictive } \\
\text { value }\end{array}$ \\
\hline H\&E & $79 \%$ & $100 \%$ & $100 \%$ & $82.6 \%$ \\
\hline PAS- AB & $100 \%$ & $100 \%$ & $100 \%$ & $100 \%$ \\
\hline
\end{tabular}

\section{DISCUSSION}

Metaplasia can be defined as the replacement of a mature cell type by another mature cell due to various reasons, especially chronic irritation (Burke and Tosh, 2012, pp. 494-499). When it comes to esophagus, mucus-secreting columnar cells replace esophageal squamous epithelial cells damaged as a result of chronic irritation caused by GERD, and this condition is called intestinal metaplasia (Spechler and Souza, 2014, pp. 836-845). This intestinal metaplasia in the esophagus is considered to be precancerous due to its role in the development of esophageal carcinoma (Spechler and Souza, 2014, pp. 836-845). Intestinal metaplasia as a result of GERD is called Barret's esophagus and it is known to affect 2-7\% of western societies (Spechler et al, 2011, pp. e18-e52.).

Increase in sedentary life and changes in eating habits -especially living at home due to the COVID-19 pandemic- many reasons such as tobacco products use and obesity increase the risk of Barret's esophagus (Naini et al, 2016, pp. e45-66.). Considering the Barret's esophaguscarcinogenesis relationship, endoscopic interventions and histopathological sampling are required to detect tumor development at an early stage. In current guidelines, it is said that the diagnosis of Barret's esophagus must be made with the presence of $\geq 1 \mathrm{~cm}$ columnar epithelium of the gastroesophageal junction and the presence of intestinal metaplasia in the histopathology of biopsy (Shaheen et al, 2016, pp. 30-50). However, due to the existence of contradictory publications related to adenocarcinoma development and intestinal metaplasia, the pitfalls of sampling location and the differences between the observers, it is important to clearly detect intestinal metaplasia without any doubt (Mukaisho et al, 2019, pp.319-330 ; Kelty et al, 2007, pp. 1271-1274; Hvid-Jensen et al, 2011, pp. 1375-1383; Faller et al, 2003, pp.597-601 ).

Defining and grading intestinal metaplasia in histopathological evaluation is critical for the follow-up of the cases (Haggitt and Dean, 1985, pp. 153-166). Although intestinal metaplasia can be detected on H\&E sections, it is much easier to detect and grade in histochemically stained sections containing $\mathrm{AB}$. In pathology laboratories, there are pathologists who perform $H \& E$ before evaluating intestinal metaplasia and evaluate $A B$ if there is doubt, as well as pathologists who evaluate $\mathrm{H} \& \mathrm{E}$ and $\mathrm{AB}$ sections simultaneously. In this 
study, the relationship of the two views with each other was investigated, and a strong relationship was found between $\mathrm{H} \& \mathrm{E}$ sections and PAS-AB sections.

Due to the importance of oesophageal carcinomas and their precursors, the specificity of $\mathrm{H} \& \mathrm{E}$ and PAS-AB histochemistry compared in establishing the definitive diagnosis of intestinal metaplasia was found to be $100 \%$ in both methods, whereas the sensitivity of H\&E (79\%) was found to be lower than the sensitivity of PAS-AB (100\%). Similarly, while the positive predictive values of both methods were $100 \%$, the negative predictive value of $\mathrm{H} \& \mathrm{E}$ (82.6\%) was lower than the negative predictive value (100\%) of PAS-AB. When this situation is examined in detail, it is noteworthy that in cases with intestinal metaplasia score 2 and 3, both methods detected the same number of cases, and the cases with different scores were the score 1 group. The reasons for this situation may be that the area of intestinal metaplasia is only visible in the PAS-AB section because of the small area, or the occurrence of intestinal metaplasia at the time of trimming, or low section quality.

\section{CONCLUSION}

The main goal in the histopathological evaluation of intestinal metaplasia is to detect positive cases. Since negative cases mean less significance, higher sensitivity and negative predictivity values should be preferred rather than $100 \%$ specificity and positive predictivity values observed in $\mathrm{H} \& \mathrm{E}$ sections. Considering these conditions, the use of an auxiliary histochemistry containing $\mathrm{AB}$ has the advantages of shortening the reporting time as well as leading to the correct diagnosis. In addition, studies have reported that taking more biopsies enables detection of more intestinal metaplasia (Harrison et al., 2007, pp.1154-1161). The possibility that detection of intestinal metaplasia with PAS-AB application will decrease the need for more tissue loss is also suggested with this study. As a disadvantage, an extra section is being examined, which is negligible since PAS-AB evaluation is not challenging in the stomach-esophagus.

In conclusion, at the end of this study, which has no methodological example in the literature, it is thought that histochemical additional examination including $\mathrm{AB}$ is superior to H\&E in Barret's esophagus (Qureshi et al, 2018, pp. 939-946), which is one of the important lesions in esophageal carcinogenesis.

\section{Author contributions:}

O.E. and Y.A. conceived the presented idea. O.E., G.F.G, Y.A. planned the research and collected data. O.E., G.F.G, Y.A. contributed to the interpretation of the results. Y.A. and G.F.G performes statistical analysis. O.E. and Y.A. took the lead in writing the manuscript. All authors provided critical feedback and helped shape the research, analysis, and manuscript.

\section{Statement of Funding:}

There is no funding for this research. 
Comparison of hematoxylin \& eosin $(H \& E)$ staining and periodic acid schiff-alcian blue (PAS-AB) histochemistry in esophageal biopsies in terms of intestinal metaplasia

Ertener et al.

\section{Statement of Conflict of interest:}

The authors declare that they have no conflict of interest.

\section{REFERENCES}

Bujanda DE, Hachem C. Barrett's Esophagus. Mo Med. 2018 May- Jun;115(3):211-3. PMID: 30228724; PMCID: PMC6140158.

Burke ZD, Tosh D. Barrett's metaplasia as a paradigm for understanding the development of cancer. Curr Opin Genet Dev 2012;22:494-9.

De Palma GD. Management strategies of Barrett esophagus, World J Gastroenterol 2012;18:6216-25.

Faller G, Borchard F, Ell C, et al. Histopathological diagnosis of Barrett's mucosa and associated neoplasias: results of a consensus conference of the Working Group for Gastroenterological Pathology of the German Society for Pathology on 22 September 2001 in Erlangen. Virchows Archiv : an international journal of pathology. 2003;443:597-01.

Fiocca R, Mastracci L, Milione M, Parente P, Savarino V; Gruppo Italiano Patologi Apparato Digerente (GIPAD); Società Italiana di Anatomia Patologica e Citopatologia Diagnostica/International Academy of Pathology, Italian division (SIAPEC/IAP). Microscopic esophagitis and Barrett's esophagus: the histology report. Dig Liver Dis. 2011 Mar;43 Suppl 4:S319-30. doi: 10.1016/S1590-8658(11)60588-4.

Gerson LB, Shetler K, Triadafilopoulos G. Prevalence of Barrett's esophagus in asymptomatic individuals. Gastroenterology. 2002;123:461-7

Haggitt RC, Dean PJ. Adenocarcinoma in Barrett's epithelium In: Spechler SJ, Goyal RK, eds. Barrett's esophagus: pathophysiology, diagnosis, and management. New York: Elsevier, 1985;153-66.

Harrison R, Perry I, Haddadin W, et al. Detection of intestinal metaplasia in Barrett's esophagus: an observational comparator study suggests the need for a minimum of eight biopsies. The American journal of gastroenterology. 2007;102:1154-61.

Hayeck TJ, Kong CY, Spechler SJ, Gazelle GS, Hur C. The prevalence of Barrett's esophagus in the US: estimates from a simulation model confirmed by SEER data. Dis Esophagus 2010;23:451-7.

Hvid-Jensen F, Pedersen L, Drewes AM, Sorensen HT, Funch-Jensen P. Incidence of adenocarcinoma among patients with Barrett's esophagus. The New England journal of medicine. 2011;365:1375-83. 
Comparison of hematoxylin \& eosin $(H \& E)$ staining and periodic acid schiff-alcian blue (PAS-AB) histochemistry in esophageal biopsies in terms of intestinal metaplasia

Ertener et al.

Katz PO, Gerson LB, Vela MF. Guidelines for the diagnosis and management of gastroesophageal reflux disease. Am J Gastroenterol 2013;108:308-28.

Kelty CJ, Gough MD, Van Wyk Q, Stephenson TJ, Ackroyd R. Barrett's oesophagus: intestinal metaplasia is not essential for cancer risk. Scand J Gastroenterol. 2007;42:1271-4.

Locke GR 3d, Talley NJ, Fett SL, Zinsmeister AR, Melton LJ 3d. Prevalence and clinical spectrum of gastroesophageal reflux: a population-based study in Olmsted County, Minnesota. Gastroenterology. 1997;112:1448-56.

Mukaisho KI, Kanai S, Kushima R, et al. Barretts's carcinogenesis. Pathol Int. 2019 Jun;69(6):319-30. doi: 10.1111/pin.12804.

Naini BV, Souza RF, Odze RD. Barrett's Esophagus: A Comprehensive and Contemporary Review for Pathologists. Am J Surg Pathol 2016;40:e45-66.

Pech O. Screening and Prevention of Barrett's Esophagus. Visc Med. 2019 Aug;35(4):210-214. doi: 10.1159/000501918.

Peters Y, Al-Kaabi A, Shaheen NJ, et al. Barrett oesophagus. Nat Rev Dis Primers. 2019 May;5((1)):35.

Qureshi AP, Stachler MD, Haque O, Odze RD. Biomarkers for Barrett's esophagus - a contemporary review. Expert Rev Mol Diagn 2018;18: 939-46.

Shaheen NJ, Falk GW, Iyer PG, Gerson LB, American College of G. ACG Clinical Guideline: Diagnosis and Management of Barrett's Esophagus. Am J Gastroenterol 2016;111:30-50.

Shalauta MD, Saad R. Barrett's esophagus. Am Fam Physician. 2004 May 1;69(9):2113-8. PMID: 15152957.

Spechler SJ, Sharma P, Souza RF, Inadomi JM, Shaheen NJ. American Gastroenterological Association technical review on the management of Barrett's esophagus. Gastroenterology 2011;140(3): e18-e52.

Spechler SJ, Souza RF. Barrett's esophagus. N Engl J Med. 2014 Aug 28;371(9):836-45. doi: 10.1056/NEJMra1314704.

Weusten B, Bisschops R, Coron E, et al. Endoscopic management of Barrett's esophagus: European Society of Gastrointestinal Endoscopy (ESGE) Position Statement. Endoscopy. 2017 Feb;49((2)):191-8. 